\title{
Foreign Investments in Development, does it really matter? An analysis under Pakistan's Perspective
}

\author{
Dr. Sadaf Mustafa (Corresponding author) \\ Department of Commerce, University of Karachi \\ Sumair Farooq \\ Department of Public Administration, University of Karachi \\ Prof. Dr. Syed Shabib ul Hassan \\ Department of Public Administration, University of Karachi
}

\begin{abstract}
Foreign investments' (F.D.I) remains a 'substantial element' in the economic development of developing nations, such as Pakistan. In recent times, the F.D.I received a greater consideration as a growth accelerating catalyst in the developing economies. As the F.D.I assists a country in terms of better technology, transfer of skills and the much-required money for development. Studies validate the relationship between the F.D.I and 'Gross domestic Product' (G.D.P) with empirical findings. Study uses longitudinal data for the past 21 years, from 1996 till 2016 in order to investigate the effect of F.D.I on the economic development of Pakistan. Apart from F.D.I, other variables such as Political stability, terrorism and Trade openness too included in this study. A 'least square technique' is smeared to empirically test impact of 'independent variables' on G.D.P. Results demonstrates F.D.I puts a positive impact in the 'economic growth', and it is apparent with the help of statistics that there is a greater F.D.I impact whenever there are open trade policies in the country.
\end{abstract}

Keywords: G.D.P, F.D.I, Trade Openness, Terrorism, Political Instability, Capital accumulation, Capital investments, Capital stocks, International economics, Time series, Time series analysis, Growth capital, Emerging technology

DOI: $10.7176 / \mathrm{PPAR} / 9-2-08$

\section{Introduction}

Today, F.D.I is the prime source of 'capital formation' throughout the world (UNCTAD, 2O18), specifically in the developing countries such as Pakistan (Iqbal, Ahmed, Haider, \& Anwar, 2013). A number of researches which scrutinized how the F.D.I contributes in the growth and economic development in developing countries such as (Knoerich, 2017; Crespo \& Fontoura, 2007; Fan, Emma, \& Xiaoqin. 2002; Ghauri \& 'Yamin, 2009; Gorg \& Strobl, 2001; Moran, Graham, \& Blom-strom, 2005). Numerous studies illustrate F.D.I puts an encouraging impact on G.D.P of the host nation. Balasubramanyan, Salisu, \& Sapsford (1996) Observes that F.D.I accelerates the economic development of the host nation and the influence is stronger in the export-oriented countries. (Todaro \& Smith, 2003; Hayami \& Godo, 2001) in their books argue that F.D.I inflows fills the gap between the desired and local investment level and at the same time it also increases the tax revenues of the host countries. The F.D.I, as a growth accelerating catalyst in the developing economies has gathered significant attention in recent years. Economists are investigating in what way inflow of F.D.I affects the economy of host nation. F.D.I plays an important part in the economic development, if it is supplemented with healthier trade freedom and an all-inclusive economic policy (Iqbal, Ahmed, Haider, \& Anwar, 2013). However, Alfaro, (2003) argued that the impact of F.D.I varies according to the type and policies adapted by the host nation for its trade and F.D.I regulation. Nonnenberg \& Mendonca, (2004) described that higher F.D.I inflow is also dependent upon the economic growth. The F.D.I role for being an important component of capital inflow is sometimes debated, however the benefits outnumber the price.

Additionally, F.D.I alleviate economic development and also considered to be the swiftest way in terms of technology transfer, skill attainment, market competitiveness and unemployment reduction (Khan, 2007). F.D.I allows the host nation to touch an investment level which is beyond their capacity, thus this helps in advancing the G.D.P and economic growth. It also offers the much-needed means like capital, management skills, technology and entrepreneurial aptitude. These will help a country to industrialize, develop and to create more 
jobs. That is why most of the developing nations know the potential of F.D.I, and for that reason they try to liberalize their investment policies. For the same reason we are doing the study in this respect to find a link amongst F.D.I and G.D.P in Pakistan's perspective.

As per the data acquired from the World Bank, the F.D.I in the financial year 2000 was just 308 million dollars after that the level quickly improved in the next six years and reach its peak in the financial year 2007 of around $\$ 5,590$ million. Since then, the level decreased until 2012 to just $\$ 859$ million due to the fact of international financial crisis, terrorist attacks in the country and back to back floods in the country. After that, it observes ups and downs and at the end of financial year 2016 it was \$2,324 million. Table 1 Demonstrates the F.D.I inflows over the years.

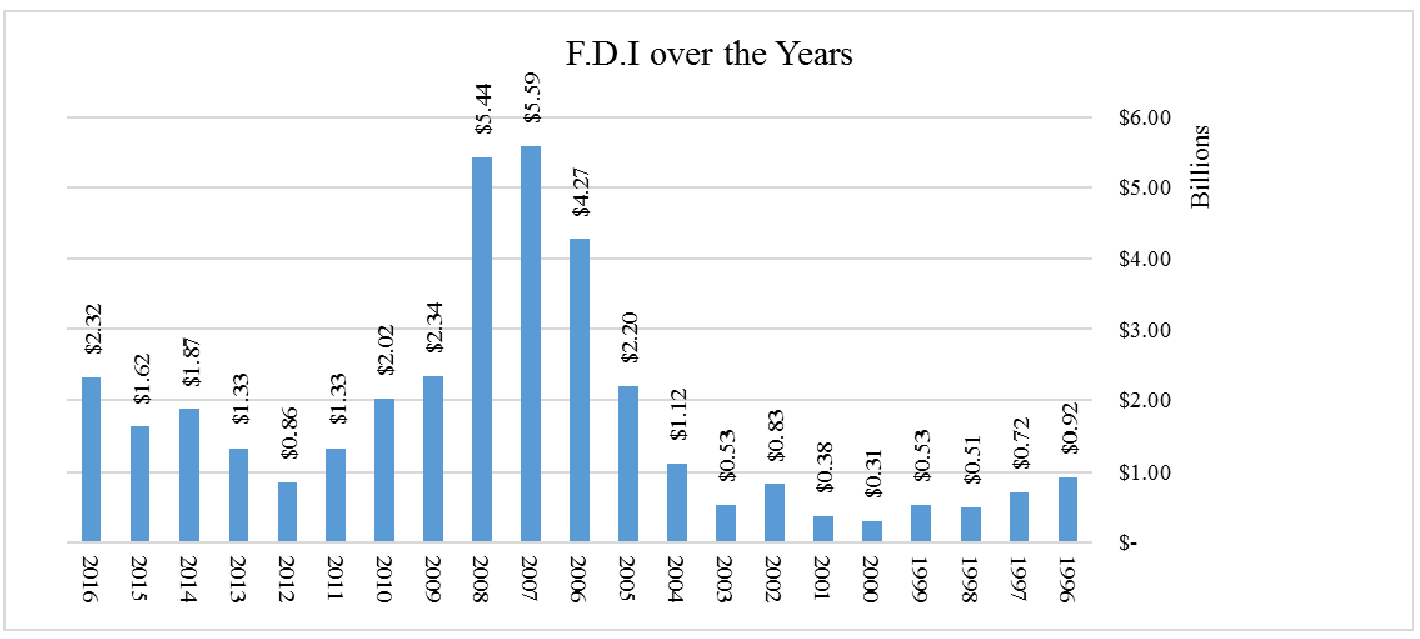

\section{Review of Literature}

Various studies discussed the connection of F.D.I and G.D.P. Arshad, (2012) weighed a long-run link between trade, G.D.P and F.D.I in Pakistan. time period of his study spanned between 1965 till 2005 and VAR model is applied in the data. The article concludes that F.D.I puts no significant influence on G.D.P, even though there is an impact of import and export on G.D.P.

Farkas, (2012) checks the effect of F.D.I on G.D.P by undertaking a regression analysis and conclude that F.D.I puts a positive impact on G.D.P and the outcome can be determined by the absorptive capacity of the 'host-nation', their level of human resource and' how much the financial market has developed.

Falki, (2009) used the ordinary least square method to analyses the impact of F.D.I on the G.D.P of Pakistan. other independent variables along with F.D.I are national capital, capital from abroad and labour. The time period of this study is from 1970-2001. The results of this study conclude that F.D.I puts a negative and immaterial impact on G.D.P.

Atique, Ahmed, \& Azhar, (2004) concluded in their study that impact of F.D.I is healthier in an export-oriented trade regime than the import-oriented trade regime. The data used in this study is also from 1970-2001.

Khan \& Khan, (2011) uses the time period of 1981-2008 and study an experiential link between F.D.I ('industry specific') and output under "'Granger causality and panel Co-integration. industries were taken into account to evaluate the link of F.D.I and growth. Results shows that F.D.I promotes the output in the services as well as the primary sector. However, its contribution in the manufacturing sector is insignificant. The study also suggested the government to put their efforts to attract foreign investment in these sectors so these sectors attain their shortterm goals.

Aurangzaib \& Haq, (2012) using these variables F.D.I, G.D.P, "remittance" and " "external debt"” to check the 'influence' of 'investment from abroad' on the 'economy'. A multiple regression analysis technique is used, time period covered in this study spanning from 1981 till 2010. Results concluded all the " independent variables", have 'a significant and positive' impact on the dependent variable (G.D.P).

Yousuf', Husain., \& Ahmad, 2008) scrutinize the influence of F.D.I on “imports exports”. 'Co-integration' \& 'error-correction-technique' were used and the time period used in the study was from 1973-2002. The study concluded that F.D.I negatively affects the exports in short-run but has a positive impact in the long-run. It also concludes that F.D.I has a positive impact on 'demand for imports' in short-run and long-run.

Tiwari \& Matascu, (2011) analyzed the data for 23 Asian countries and try to find out the link between F.D.I and 'economic-growth' with the help of 'panel-data-approach'. The data used in this study spanned from 1986 to 
2008. The results show that F.D.I boosts the economic-growth.

Makki \& Somwaru, (2004) concluded that F.D.I promotes domestic investment. It amalgamates positively with trade. It is also concluded that consistency and soundness in policies are the perquisites for the F.D.I to escalate G.D.P. The data is used from 66 developing countries throughout the world and results are drawn by using econometric model for production function.

Borensztein, De, \& Lee, (1998) include 69 developing countries and investigated the impact of F.D.I on economic growth. The study concludes 'F.D.I contributed more towards economic-growth when compared with local-investment'. It also describes this growth-impact (of F.D.I) depends on the level of labor-resource available for work.

\section{Conceptual Model}

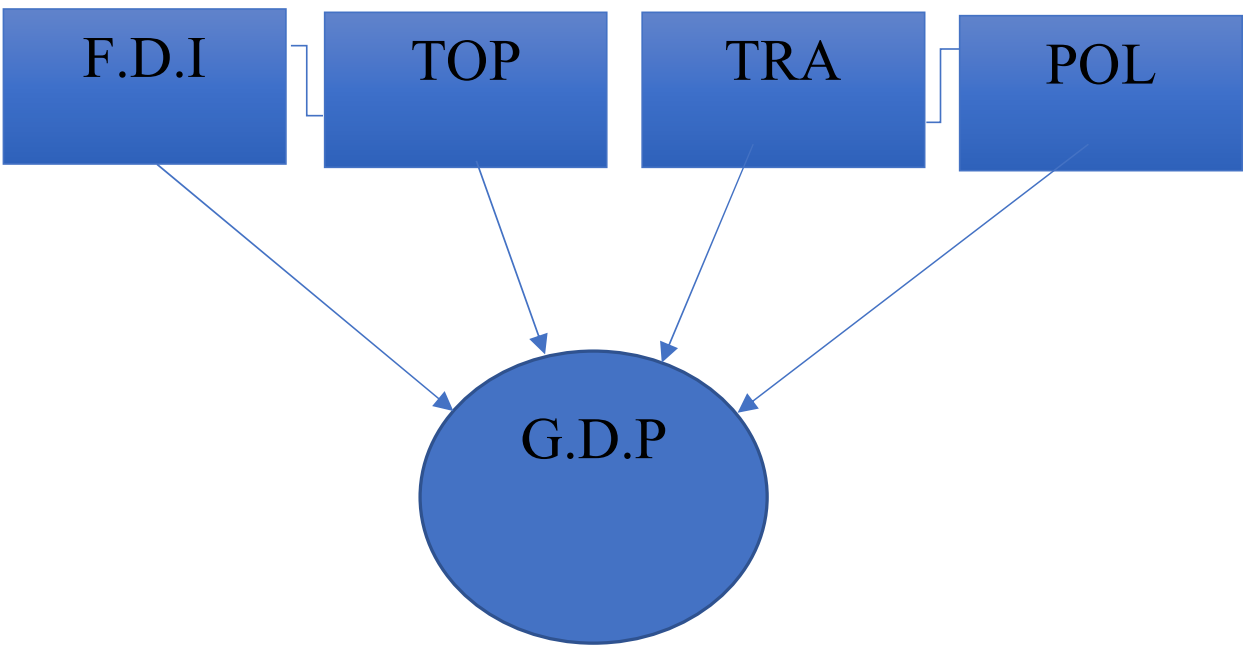

\section{Methodology}

The purpose of this study is 'assessing the link' among F.D.I and G.D.P of Pakistan. Data we used spanned through 1996 till 2016. The study includes five variables namely

1. Gross Domestic Product (G.D.P)

2. Foreign Investment (F.D.I)

3. Trade Freedom (TO)

4. Political Stability (PS)

5. Terrorism (Te)

Our Model for regression,

$$
\text { LogG.D.P }=\alpha \square \beta_{\square} \text { LogF.D.I }+\beta_{\square} \mathrm{TO}+\beta_{\square} \mathrm{PS}+\beta_{\square} \mathrm{Te}+\varepsilon
$$

Table 2: Determinants of economic performance, in Pakistan's perspective

\begin{tabular}{lcl}
\hline Variables" & 'Proxy & 'Data Source \\
\hline :Dependent Variable: & & \\
'Economic Growth' & & \\
Independent Variables: & Natural Log of G.D.P & 'World Bank \\
Foreign Investment & Natural Log of F.D.I & 'World Bank \\
Trade Freedom & TO & 'World Bank \\
Political Stablity & PS & 'World Bank \\
Terrorism & Te & 'Trade \& Economics \\
\hline
\end{tabular}

\section{Variables Defination and their Explaination}

a. Gross Domestic Product(G.D.P)

G.D.P is the dependent variable of the study. The G.D.P expressed in 'US\$'. We convert the values into 
'log-form' to aviod 'sharpness' in the data.

b. Foreign Direct Investment (F.D.I)

(Kowalski, 2000) says F.D.I is crucial and important forecaster of Economic growth. F.D.I brings resources and improved 'technology' towards economy, both considered the 'engine' of any developing economy (Heeks \& Stanforth, 2O15'.). The research try to determine the influence of this variable on the economicgrowth. The amount expressed in our data is in US\$. We convert the values into 'log-form' to aviod 'sharpness' in the data.

c. $\quad$ Trade Freedom (TO)

Trade Freedom is expressed as total exports and imports as percentage of G.D.P. We used TO as a proxy in our study

d. Political Stability $(P O)$

$$
\mathrm{TO}=(\text { Exports }+ \text { Imports }) / \text { G.D.P }
$$

Pakistan have the potential to be an economic-power of Asia, but political-instability is a severe risk for the investment as well as its economic growth. For this reason, we intend to estimate the effect of this factor on economic development aswell. The data used is taken from the World Bank Database, there they ranked the countries on the scale of -2.5 for weak towards +2.5 strong. This is a widely used data set which provides a picture of political situation of a country on annual basis. We used POL as a proxy in our study.

e. Terrorism

Terrorism is a hot issue in today's world. The menace disturbs political, social and economic system throughout the world. Few years ago, the terrorist activities in Pakistan reached their all time high and 2013 and 2014 became the deadliest years in recent times. But, thanks to the successful military operations , situation are quite good as compared to 3 years ago. But, this war against terrorism cost the economy very much. Therefore, it is intended to investigate the impact of this factor on the economy of Pakistan. We use TRA as a proxy in our study, the data taken for this variable is from Trade \& Economics website.

\section{Analysis of the Data}

Table 3: The Core of Different Stats

\begin{tabular}{llllll}
\hline Variable & No. & Mini & Maxi & 'Mean & $\begin{array}{l}\text { Standard } \\
\text { Deviation }\end{array}$ \\
\hline LogG.D.P & 21 & 24.85349 & $' 26.35417$ & 25.55478 & 0.550871 \\
LogF.D.I & 21 & 19.54561 & $' 22.44425$ & 20.96103 & 0.832688 \\
TO & 21 & -2.81 & -1.10 & -2.096 & 0.599099 \\
PS & 21 & 27.6 & 38.33 & 32.786 & 2.727564 \\
Te & 21 & 6.12 & 9.07 & 7.869 & 1.090226 \\
\hline
\end{tabular}

Table 3 displays the core stats of variables we used in our study. LogG.D.P is the dependent variable in the study. Whereas LogF.D.I, POL, TOP and TRA are the independent variables. The model consist of 21 observations.

Table 4: The unit root test of augmented dickey fuller

\begin{tabular}{lll}
\hline Variables & $\begin{array}{l}\text { ADF at } \\
\text { Level }\end{array}$ & $\begin{array}{l}\text { ADF with first } \\
\text { difference }\end{array}$ \\
\hline LogG.D.P & -3.658446 & -3.673616 \\
LogF.D.I & -3.710482 & -3.673616 \\
TO & -3.791172 & -3.933364 \\
PS & -3.673616 & ---- \\
Te & -3.875302 & -3.933364 \\
\hline
\end{tabular}

We must analyise 'stationarity' of data before examining the long-run connotation. In lieu of this we carried our an 'auggumented-dickkey-fuler-test'.

The above table underlined the outcomes of 'auggumented-dickkey-fuler-test'. Stationarity is checked at $5 \%$ confidence interval. It is clear from the table that LogG.D.P, LogF.D.I, PS and Te are 'nonstationary' 'at-level' however it becomes stationary 'at-first-diference', which implies all of them can be 'integrated' at 'orderone'. Whereas, 'TO' becomes stationary 'at-level', it implies it can be 'integrated' at 'order-zero'. 
Table 5: Statistics related to Ordinary least squares

\begin{tabular}{lllll}
\hline Variable & Coefficient & Std. Error & t-Statistics & Prob. \\
\hline C' & 21.556 & 1.507384 & 14.3003 & 0.0000 \\
LogF.D.I & 0.0759 & 0.069561 & 1.0914 & 0.0030 \\
TO & -0.0070 & 0.022197 & -0.3168 & 0.7128 \\
PS & 0.1904 & 0.293729 & 0.6482 & 0.5330 \\
Te & 0.4164 & 0.118614 & 3.5109 & 0.0066 \\
\hline
\end{tabular}

\begin{tabular}{llll}
\hline 'Rsquared' & '0.9177 & 'Mean Dependent Variable & 25.7726 \\
'Adjusted Rsquared' & $' 0.8812$ & 'S.D. dependent Variable & $' 0.4173$ \\
'SE of regression & $' 0.1438$ & 'Akaike-info-criterion & $'-0.7678$ \\
'Sum squared resid & 0.1861 & 'Schwarz-criterion & $'-0.5396$ \\
'Log likelihood & $' 10.374$ & 'HannanQuinn criterion & $'-0.7889$ \\
'Fstatistic & 25.1105 & 'DurbinWatson statistics & $' 1.4811$ \\
'Probability(Fstatistic) & $' 0.0000$ & & \\
\hline
\end{tabular}

The results of O.L.S can be elaborated in table_5. Here LogG.D.P is dependent variable. Whereas, TO, LogF.D.I, PS and Te are independent. Value of adjusted-Rquared is '00.88' and Fstatistic ' 25.11 ' which confirms the 'goodness' of the-model. The probability (Fstatistic)value is ' 0.0000 ' 'less-than 0.05 , which express 'thesignificance' of the-model. DurbanWatson-statistics for dependent variable= ' 1.48 ' which implies there is 'noautocorrelation' exists' and the regression-model assumes' that 'error_deviations' are 'un_correlated'.

The equation is shown below

$$
\operatorname{LogG.D.P}=21.56+0.07(\log F . D . I)-0.007(T O)+0.19(P S)+0.42(T e)
$$

Equation demonstrates coeffiecent of F.D.I is 'positive', t-statistics shows its' significant. However, the value is 0.07 which means for every unit increase in F.D.I, there is around 7\% increase in the G.D.P.

Trade opennes variable was found to have a negitive relationship with G.D.P , but the T-statistics shows the result is not significant.

Political stability have a positive impact but result is not significant, which may conclude that though it may positively affect the economic growth, but the impact cannot be judged by now. This is due to a volitile situation of Pakistani political and democratic arena.

Co-efficient for Terrorism is also significant and positive, rate is 0.42 . So, we can conclude that improved security situation and reduced terrorist activities had a significant positive influence on G.D.P.

\section{Conclusion}

F.D.I is playing a positive significant role in the economic development. The data for the past two decades shows a positive and significant impact of F.D.I on the development in the country. The previous literature in this regard, manifest a notion that inflow of F.D.I is not so much significant, but to some extent its significance increases as Pakistan adopted market oriented policies. The paper scrutinize the link among G.D.P and F.D.I by means of 'the-timeseries-data', takes Pakistans' perspective in the study. End result demonstrates F.D.I plays a major role towards the economy during 1996-2016. As demonstrated in previous studies, F.D.I is the crucial to economic development in several developing countries. The study recommends government should focus on infrastructure, trade transperency, stabilization of political enviornment and creating a steady macroeconomic framework in order to attract more foreign investments inflows which helps the economy growing. In recent times, the Pakistani state is spending a lot of money in combating the terrorism, and on security and defense.Government should pay attention to other factions of the society in order to distrubute the fruits of economic growth. As there are improvments in the law an order situation, so the Government can reduce the expenditure on defense and internal security gradually and spend the money on other development projects. In the end, with the help of this study we concludes that Economic growth of Pakistan depends upon its ability to attract F.D.I, which is interdependent on Trade openness, Political stability and improved law and order situation. 


\section{References}

Todaro, M. P., \& Smith, S. C. (2003). Economic development. Addison Wesley.

Alfaro, L. (2003, April). Foreign Direct Investment and Growth: Does the Sector Matter? Harvard Business School.

Arshad, M. (2012). Impact of Foreign Direct Investment on Trade and Economic. International Journal of Economics and Research, 3(4), 42-75.

Atique, Z., Ahmad, M. H., Azhar, U., \& Khan, A. H. (2004). The impact of FDI on economic growth under foreign trade regimes: A case study of Pakistan [with comments]. The Pakistan Development Review, 707-718.

Aurangzaib, \& Haq, U. (2012). Impact of foreign capital inflows on economic growth in Pakistan. European Journal of Economics, Finance and Administrative Sciences, 46(6).

Balasubramanyan, V. N., Salisu, M., \& Sapsford, S. (1996). Foreign Direct Investment and Growth in EP and IS Countries. The Economic Journal, 106, 92-105.

Borensztein, E., De, G. J., \& Lee, W. (1998). How does foreign direct investment affect economic growth. Journal of International Economics, 45(1), 115-135.

Crespo, N., \& Fontoura, M. P. (2007). Determinant Factors of FDI Spillovers - What Do We Really Know? World Development, 35(3), 410-425.

Falki, N. (2009). Impact of foreign direct investment on economic growth in Pakistan. International Review of Business Research Papers, 5(5), 110-120.

Fan, E. X. (2002). Technological spillovers from foreign direct investment-a survey. Asian Development Bank.

Farkas, B. (2012). Absorptive capacities and the impact of FDI on economic growth.

Ghauri, P. N., \& Yamin, M. (2009). Revisiting the impact of multinational enterprises on economic development. Journal of World Business, 44(2), 105-107.

Gorg, H., \& Strobl, E. (2001). Multinational companies and productivity spillovers: A meta - analysis. The economic journal, 111(475), F723-F739.

Hayami, Y., \& Godo, Y. (2001). Development Economics: From the Poverty to the Wealth of Nations. Oxford University Press.

Heeks, R., \& Stanforth, C. (2015). Technological change in developing countries: opening the black box of process using actor-network theory. Development Studies Research, 2(1), 33-50.

Iqbal, N., Ahmed, N., Haider, Z., \& Anwar, S. (2013, November). Impact of foreign direct investment (FDI) on GDP: A Case study from Pakistan. International Letters of Social and Humanistic Sciences, 16, 7380 .

Khan, A. (2007). Foreign direct investment and economic growth: The role of domestic financial sector. Pakistan Institute of Development Economics.

Khan, M. A., \& Khan, S. A. (2011). Foreign direct investment and economic growth in Pakistan: A Sectoral Analysis. Pakistan Institute of Development Economics (Working Paper 67).

Knoerich, J. (2017). How does outward foreign direct investment contribute to economic development in less advanced home countries? Oxford Development Studies, 45(4), 443-459.

Kowalski, E. (2000). Determinant of economic growth in East Asia. Research Honors Project.

Makki \& Somwaru, ('2004). 'Impact of foreign direct investment and trade on economic growth: Evidence from developing countries. American Journal of Agricultural Economics, 86(3), 795-801.

Moran, T., Graham, E., \& Blomstrom, M. (2005). Does foreign direct investment promote development? Institute for International Economics and Center for Global Development.

Nonnenberg, M. J., \& Mendonca, M. (2004, April). The Determinants of Direct Foreign Investment in Developing Countries. Social Science Research Network.

Saggi, K. (2002). Trade, foreign direct investment, and international technology transfer: A survey. 17(2), 191-235. 
Tiwari, A. K., \& Matascu, M. (2011). Economic growth and FDI in Asia: A panel data approach. Economic Analysis and Policy, 41(2), 173-188.

UNCTAD. (2018). World Investment Report. United Nations.

Yousuf, M. M., Hussain, Z., \& Ahmad, N. (2008). Economic evaluation of foreign direct investment in Pakistan. Pakistan Economic and Social Review, 46(1), 37-56. 